\title{
DEU A LOUCA NOS CONTOS DE FADAS
}

\author{
Fairy Tales Have Gone Crazy
}

\author{
Cristiane Manzan PERINE, UFU ${ }^{1}$ \\ Marisa Martins Gama HALIL, UFU ${ }^{2}$
}

\begin{abstract}
RESUMO: Sabemos que a Literatura possibilita ao leitor uma visão crítica e criativa do mundo, já que o texto literário não descortina um único significado, mas amplia-se, abrindo sentidos vários e alargando as visões sobre os sujeitos e a sociedade. Por este motivo, defendemos a importância do trabalho com a literatura na sala de aula. Seja agregada oficialmente ao currículo e trabalhada no cotidiano escolar como uma disciplina; seja de forma ocasional, trabalhada em oficinas, de modo a reforçar os conteúdos ministrados em sala de aula. Desse modo, este trabalho tem por objetivo relatar a experiência frutuosa de um projeto de pesquisa e extensão desenvolvido através do ensino de literatura em contexto de escola pública. A escola pôde incentivar a leitura aos alunos ao fornecer a possibilidade de freqüentarem oficinas em horário extra-classe. Os ministrantes das oficinas foram professores estagiários prestes a terminar o curso de Letras, cursando a disciplina Prática de Ensino de Literatura e orientados por um professor experiente. Pudemos perceber que os alunos se sentiram mais motivados e interessados em aprender e conseguiram adquirir uma visão mais ampla de literatura, que vai muito além daquela fixada nos livros didáticos.
\end{abstract}

PALAVRAS-CHAVE: literatura; oficina; professor em formação

ABSTRACT: We all know that literature enables the reader to develop a critical and creative view of the world, as the literary text doesn't open only one meaning, but amplifies itself, unlocking several meanings and extending the visions upon the subject and the society. For this reason, we believe in the importance of the work with literature in the classroom. Either officially connected to the curriculum and used in the daily school life as a subject or in an occasional way, used in workshops, as means of reinforcing the contents provided in the classroom. Thereby, this research has as objective to report the fruitful experience of a research and extension project developed through the teaching of literature in public schools. The school had a new chance to encourage the students to read by providing them the possibility to attend the workshops apart from the classes. The teachers were students taking a practical subject on teaching literature and they were guided by an experienced professor. We could perceive that the students felt more motivated and interested in learning and succeeded in having a greater view upon literature, which goes beyond the course book.

KEYWORDS: literature; workshop; pre-service teacher

\footnotetext{
${ }^{1}$ Graduanda na Universidade Federal de Uberlândia.

${ }^{2}$ Doutora, docente da Universidade Federal de Uberlândia e orientadora do projeto.
} 


\section{INTRODUÇÃO}

Acreditando na possibilidade de pensar e re-pensar a sala de aula de literatura, este ensaio se propõe analisar e refletir sobre uma prosposta de leitura dos contos de fada em sala. Nesse sentido, este ensaio se configura como apresentação de um projeto de extensão, o qual reune um caráter teórico e prático. Tal projeto denominado "Deu a louca nos contos de fadas", serviu de espaço de experiência para futuros professores, alunos estagiários, muitos deles prestes a adentrarem a sala de aula pela primeira vez e, ao mesmo tempo, foi importante para os alunos de escola pública que participaram do projeto, uma vez que foi um espaço de encontros, troca de experiências e aprendizagem. O principal tema abordado foi o gênero caracterizado por narrativas curtas e populares, conhecidas como contos de fadas. Os contos de fadas nasceram entre os celtas por volta de 1600 a.C, surgiram da imaginação coletiva e eram contados oralmente (BETTELHEIM, 2002). Muito tempo depois começaram a ser escritos, e chegaram até nós através de Perrault, na França, dos Irmãos Grimm, na Alemanha, e de outros autores. Hoje são vistos em filmes, desenhos animados e até mesmo histórias em quadrinhos, tais como as histórias de Chapeuzinho Vermelho e o conto dos Três Porquinhos. Em sala de aula são usados desde os primeiros anos de alfabetização como forma de incentivar o gosto pela leitura. A finalidade primordial do projeto aqui relatado foi retomar o gênero conto de fadas com o público adolescente através de oficinas e, além disso, proporcionar espaço para de prática docente para os professoras em formação.

Cumpre ressaltar que a oficina a ser descrita faz parte de um projeto maior entitulado "Oficinas de Narrativa Literária", o qual abordou diversas temáticas ligadas à obras narrativas na literatura, abarcando a triádica que fundamenta a noção da universidade: ensino, pesquisa e extensão. Um grupo de dez alunos esteve envolvido neste projeto de extensão e, de forma individual ou em grupos, desenvolveram diferentes oficinas. Relatamos neste ensaio a oficina da qual participamos como professoras em formação, a definição de contos de fadas que norteou este trabalho, a justificativa de escolha por tal gênero, o contexto de pesquisa e participantes e uma breve descrição da realização da oficina. 


\section{O QUE SÃO CONTOS DE FADAS?}

Traçamos primeiramente uma breve definição do que são contos de fadas. Podemos definir o conto como um gênero literário, é uma narrativa concisa e curta em extensão. Um conto possui características estruturais próprias, o enredo em geral é simples, sem complicações e tempo e espaço são bem delimitados. É uma narrativa linear que conta sempre com um narrador, um personagem principal e um incidente predominante, um clímax (WERNER, 1999). Um questionamento inicial que aparece quando nos remetemos aos contos de fada, é justamente porque recebem este nome, uma vez que nem sempre há presença de fadas. As fadas podem ou não aparecer no enredo, a escolha das fadas faz alusão aos personagens que desempenham o papel de mediadores, aqueles que aparecem na história inesperadamente em momento de angústia e ajudam o herói de alguma forma, os quais serão retomados adiante. Involuntariamente, ao ouvir a expressão contos de fadas, o que nos vem à mente de imediato são as conhecidas frases: "Era uma vez, num reino distante..."que são como palavras mágicas que nos fazem adentrar num novo mundo, um mundo em que tudo é possível e, após grandes dificuldades, o personagem principal quase sempre tem um final feliz. É o famoso: “(...) e foram felizes para sempre”.

Dentre as características pertinentes aos contos de fadas cabe ressaltar que há uma nítida distinção entre o bem o mal, ou seja, os personagens que são apresentados como bons e os personagens do mal. Esses, no desenlace da trama, são punidos por suas atitudes, humilhados, e podem até mesmo conhecer a morte; faz-se justiça, fazendo prevalecer a vitória do bem sobre o mal. Os mocinhos têm sempre a imagem de serem pessoas generosas, com bom coração, que sofrem e são injustiçadas por algum motivo, o qual o conto nos dará a conhecer, mas ao final será recompensado por seu sofrimento. Tal fronteira que separa o bem e o mal enfatiza fortemente a característica do personagem, não há momentos de hesitação entre a bondade e a maldade, as características do ser são bem definidas.

Os nomes dos personagens são populares, como é o exemplo do clássico João e Maria. No entanto, os personagens podem não ter nomes, o que facilita ainda mais nossa identificação com os personagens; é o que percebemos em A Bela Adormecida, Chapeuzinho Vermelho, O Pequeno Polegar, A Gata Borralheira, O Gato de Botas, dentre outros. 
Embora tal constatação seja bastante explícita, o personagem principal, o heroi, passará por diversas aventuras e dificuldades, num processo de crescimento e superação para ao final ser recompensado com o tão esperado final feliz, o que aparece ligado ao amor, à formação de um casal, e deixa no ar a ideia de uma história que pode ter continuidade, atiçando a imaginação do leitor. A nosso ver, a concretização do final feliz é o fato que mais atém a atenção das pessoas aos contos de fadas, já que isso cria esperanças que todos podem passar por turbulências, superá-las e serem premiados com o final feliz. Como expõe Robert:

\footnotetext{
Ele (o conto de fadas) descreve essencialmente uma passagem - passagem necessária, difícil, cheia de mil obstáculos, precedida de provocações aparentemente insuperáveis, mas que tem um final feliz apesar de tudo. Sob as fabulações mais inverossímeis, desponta sempre um fato bem real: a necessidade de o indivíduo passar de um estado a outro, de se formar através de metamorfoses dolorosas que só terminam com o seu acesso a uam verdaeira maturidade. (ROBERT, 1987, p.9 apud. SILVA, p.81)
}

Pode-se dizer que as histórias de fadas ainda exercem muita sedução junto a leitores de qualquer idade nos dias de hoje. Os chamados contos de fadas modernos são encontrados em livros, filmes, desenhos animados, poesias e até mesmo nas novelas. Várias releituras dos clássicos contos de fadas têm sido criadas, desde as parafrásticas, nas quais há uma adaptação que segue as mesmas linhas do texto de origem; às parodísticas, nas quais há uma negação do texto primeiro. As paródias, hoje, são o tipo de intertextualidade mais recorrente em relação à releitura dos contos de fadas. A impressão que temos é que com essas paródias narrativas, e consequentemente, o surgimento de novas histórias, estas se tornam mais próximas de nossa realidade, de nosso cotidiano e, consequentemente, têm mais facilidade em chamar nossa atenção. Paródia é um conceito que nos remete a Bakhtin (1987), é uma intertextualidade que produz um efeito cômico. A nosso ver, à primeira vista, corremos o risco de agir com certo preconceito e ver tais obras como cópia ou mesmo plágio, no entanto, trata-se apenas de estabelecer um novo encontro com o texto fonte.

\section{POR QUE CONTOS DE FADAS?}

A ousadia da prática investigativa a ser descrita a seguir, reside na enorme capacidade de encantar e entreter, crianças, jovens e adultos, que os contos de fadas 
apresentam. Os contos de fadas fazem parte do gosto popular. Tendo em vista que os contos de fadas constituem uma narrativa de tom casual, as estórias são simples e fáceis de entender e, por isso, mesmo envolventes. Somado a isto, são prazerosas, evocam emoções, medo, fascínio, apreensão, alegria, dentre tantos outros sentimentos, somos convocados a compartilhar dos mesmos sentimentos dos personagens. Talvez seja esse o motivo pelo qual despertam sutilmente nosso interesse e têm grande aceitação na sociedade. Como expõe Bettelheim (1980), os contos de fadas têm capacidade de falar simultaneamente a todos os níveis da personalidade humana pelo uso de uma linguagem muito simbólica sem recorrer tanto ao pensamento lógico; em outras palavras, são narrativas que não envelhecem, como veremos adiante, ganham nova cara e novo corpo, renascem a cada nova versão criada.

Uma de nossas preocupações era justamente o espaço concedido à literatura na grade curricular das escolas públicas, o qual é muito restrito e por vezes insatisfatório. A aula de literatura aparece à sombra da aula de língua portuguesa. Em nossa vivência em sala de aula da rede pública, o que constatamos é que um belo texto literário é muitas vezes tomado apenas para remeter a algum item gramatical e fazer a ligação com a aula de português ou é tomado apenas para uma interpretação de texto superficial, a qual ignora que "estamos falando do encontro de dois leitores, do autor e de seu leitor. "São dois mundos que se tocam" (SILVA, 2008) e, portanto, a leitura de um mesmo texto nunca será igual para dois leitores. E, nesse universo de encontros, percebemos nitidamente o que Jorge Larrosa (2000, p. 139) outrora havia dito, o texto convoca o leitor e lhe oferece hospitalidade, há então um encontro da hospitalidade do livro e a disponibilidade do leitor, o que ele define como mútua entrega "condição de um duplo devir". Da forma como vem sendo abordada a literatura, os alunos têm um contato muito superficial com o que é literatura e isso acaba repercutindo em suas vidas e na aversão à leitura que boa parte deles apresenta. Percebe-se amplamente a presença da literatura em sala de aula apenas como instrumento para ensinar algo e abordada apenas por uma função utilitarista. Não que a literatura não possa ter função didática, ela ensina, e muito, por si própria. Porém, tomá-la com uma simples missão de ensinamento, de transmissão de valores, compromete a imaginação, o despertar das emoções e a criatividade dos leitores. Nada pode substituir o valor estético da obra literária, a expressão do belo, da arte. O valor estético é, por si só, valor educativo. Na colocação de Perroti (1986, p.70), "pelo próprio instrumento de que se utiliza, a literatura é uma lição permanente de linguagem." Nossa proposta foi, então, levar os 
alunos participantes do projeto a um novo encontro cheio de descobertas com a literatura. E esse encontro se deu através dos contos de fadas. Compartilhamos com a visão de Silva (2008), a qual afirma que:

\begin{abstract}
Se o professor despertar a atenção do jovem leitor para a relação que existe entre o processo de construção do texto e seu significado, ele será capaz de apreciar mais intensamente as obra que ler e, mais do que isso, será capaz de prosseguir em seu percurso de leitor sozinho. Para que isso possa acontecer, porém, é preciso que o professor se assuma de fato como docente, ou seja, aquele que conduz. Conduzir não é cobrar, nem punir, nem intimidar. É andar junto. Um passo mais à frente, talvez, por já conhecer o caminho, mas permitindo ao grupo que lidera o prazer da descoberta de novas trilhas e novas paisagens. (p.45)
\end{abstract}

Nossa proposta é que eles possam mergulhar nestes contos, fazendo associações pessoais e criando suas próprias visões sobre estas histórias. Além disso, a forma como serão abordados, aliados à produção cinematográfica, história em quadrinhos, séries de TV e músicas, que são outros fatores que atraem muito os alunos pode resultar em uma combinação muito atrativa para os mesmos. São formas diferentes de interagir com os alunos, fazê-los sentir, pensar e até viver aquela fantasia, seja qual for o lugar, o tempo ou a cultura ali representados. O professor deve saber aproveitar o atraente, rico e variado mundo da fantasia, como uma inesgotável fonte de motivação didática e de uma grande importância pedagógica. Este trabalho foi desenvolvido através de fundamentação teórica e prática por parte do professor orientador e dos alunos em sala de aula. Por meio de oficinas como esta, o professor pode trabalhar a criatividade do aluno, os sentidos, dentre outros aspectos.

\title{
CONTEXTO DE PESQUISA E PARTICIPANTES
}

Temos que analisar um contexto de pesquisa com dois tipos de participantes. Temos de um lado um grupo alunos do curso de Letras, cursando a disciplina Prática de Ensino de Literatura, em uma universidade federal do interior de Minas Gerais. Tal disciplina reúne carga teórica e prática. Segundo sua ementa, sua meta é oferecer um conhecimento de práticas reais educacionais relacionadas ao ensino e à prática de literatura, buscando-se incitar no acadêmico de Letras a sua construção como sujeito que tem domínio de sua própria prática e de seu papel social. Nesse âmbito, coloca-se relevo sobre o educador que tem como tarefa fundamental a formação de leitores críticos e criativos. 
Por outro lado, temos os alunos uma escola da rede estadual da cidade. $\mathrm{Na}$ escola funciona um projeto conhecido como PROETI ou Projeto Escola de Tempo Integral. Tal projeto entrou em vigor na escola em 2007 e, desde então, visa ao reforço escolar e a um trabalho extracurricular com turmas do ensino fundamental $\left(5^{\circ}\right.$ ao $9^{\circ}$ ano). Aqueles alunos que se interessam pelo projeto, mediante consentimento dos pais podem participar do mesmo. Assim sendo, os alunos cumprem o currículo básico à tarde (turno regular) e, pela manhã, participam do PROETI. O projeto busca um preenchimento do tempo dos alunos de forma produtiva, uma vez que passam o dia envolvidos com a escola. Sua matriz é voltada a proporcionar aulas de reforço, visto que os alunos têm tempo destinado a fazer os deveres de casa sob acompanhamento e lhes são oferecidas oficinas e atividades multidisciplinares diversas. Como informado na descrição do programa, o PROETI visa disponibilizar espaços e propostas sócioeducativos que proporcionem o desenvolvimento integral e a interação da comunidade estudantil por meio da realização de experiências inovadoras, possibilitando a melhoria da qualidade de vida e a inclusão social. Conforme o expresso no site do projeto, a proposta atende crianças e jovens, preferencialmente as que estão em situação de vulnerabilidade e risco social bem como as que apresentem problemas de aprendizagem. Acrescentamos ainda que o PROETI conta com um espaço físico privilegiado, muito amplo, com quadras, salas de aula bem equipadas com recursos multimídia, auditório e área ao ar livre. Assim, nossa intervenção foi realizada junto aos alunos do $6^{\circ}$ ano, com faixa etária entre 11 e 12 anos, totalizando 40 alunos, os quais faziam parte do PROETI. A escolha em trabalhar como $6^{\circ}$ ano veio de um acordo com os coordenadores do PROETI, visto que nossa intenção era levar o projeto à alunos que estivessem iniciando o ciclo do ensino fundamental.

\section{A OFICINA: "DEU A LOUCA NOS CONTOS DE FADA"}

Para se entender a oficina, procedemos, a seguir, com uma detalhada descrição das atividades realizadas. Num primeiro momento, começamos a dialogar com os alunos a respeito da visão que eles tinham a respeito dos contos de fadas. Abrimos a conversa com alguns questionamentos, tais como: "Quais são os contos de fadas que vocês conhecem? Quais são os personagens mais comuns? Através de que meios vocês tiveram contato com os contos de fadas? Vocês gostam de contos de fadas? 
Na sequência, mostramos um trecho do filme Shrek $2^{3}$ como vídeo motivador para guiar a discussão e adentrar no tema dos contos de fadas modernos. No trecho escolhido, apareciam diversos personagens famosos oriundos de outras histórias clássicas. Havia um concurso de música que parodiava o programa americano American Idol, e os candidatos eram personagens de contos de fadas cantando músicas famosas. Após o trecho, foi pedido aos alunos que identificassem quais os personagens famosos estiveram ali presentes. Neste ponto, os alunos participaram bastante da oficina e se mostraram animados diante do Shrek, que nos pareceu ser um personagem que agrada a todos. Ficaram muito agitados também pela menção ao programa americano, o qual tem uma versão brasileira muito popular. A partir das ilustrações dos alunos, fomos questionando sobre as histórias originais em que tais personagens apareciam e os incentivamos a contar estas histórias. Neste momento, tivemos a oportunidade de fechar esta discussão inicial falando numa perspectiva teórica sobre o que são contos de fadas, suas características e estruturas, procurando responder as questões antes levantadas, numa breve exposição teórica.

O próximo passo foi uma tentativa de ouvir mais efetivamente a voz dos alunos, dar atenção ao que eles tinham a dizer e, ao mesmo tempo, proporcionar um espaço de interação entre alunos e professoras estagiárias. Guiamos então a discussão. Primeiro eles tiveram que relembrar a história dos Três Porquinhos para, em seguida, assistir a um vídeo em que a mesma aparece de forma breve e cantada, numa primeira aproximação história e música. Os participantes cantaram espontaneamente e acompanhando com palmas a canção “Quem tem medo do lobo mau?". Tal acontecimento nos surpreendeu, pois temíamos que eles não gostassem na música, pelo fato de que se trata de uma canção de tom infantil e a própria história cantada dá um ar infantil; no entanto, eles se mostraram atentos e pediram para que repetíssemos o vídeo, e assim o fizemos. Isso é próprio dos contos de fadas, a capacidade de nos convidar a adentrar um reino infantil. A história seguinte foi a de João e o Pé de Feijão; eles discutiram a história e depois assistiram a uma versão em que há apenas ilustrações, relembrando o poder das imagens ao contar uma história. O mesmo procedimento foi adotado com Alice, após discutida sua versão original, assistimos a um trecho do filme "Alice no país das maravilhas"

${ }^{3}$ SHREK 2. Direção de Andrew Adamson; Kelly Asbury; Conrad Vernon. EUA: DreamWorks SKG. DVD (1h 45min), legendado. (EUA, 2004) 
comentários que fizeram, a maioria disse ter visto o filme. Após esta sessão de contar histórias, nos remetemos a Branca de Neve e os Sete Anões e pedimos que os alunos contassem essa história em detalhes. Dois alunos se ofereceram para ir à frente da turma contar a história aos colegas.

Por fim, os alunos assistiram a um episódio de Chaves ${ }^{5}$, um seriado mexicano considerado um fenômeno de audiência com mais de 40 anos de sucesso no Brasil. Por ser antiga, a série conta com recursos de produção muito simples. Parou de ser gravada em 1980, porém, continua a ser reprisada em mais de 30 países pelo mundo, incluindo Japão, China, Austrália, França, Itália, Portugal e Estados Unidos, conforme informado no site oficial da série. O episódio mostrado aos alunos começa com o professor "Girafales" tentando começar a aula e sendo impedido pelos alunos que querem que ele conte uma história. Ele afirma não saber contar nenhuma história. Então aparece o super heroi Chapolin, que intimida o professor, dizendo que vai contar uma história: "E não me diga que você não gosta de contos de fadas!" No episódio escolhido, há uma releitura da obra Branca de Neve e os Sete Anões de forma cômica. Para exemplificar, na história temos um espelho mágico que é ligado como se fosse uma TV, com direito a comerciais entre uma transmissão e outra, um rei que morre de pneumonia galopante, um caçador que pergunta que pecado cometeu Branca de Neve, e a rainha que responde: "ser mais bonita que eu”, e o caçador replica: "uhh, então vou passar a vida cortando pescoços de moças por aí, um atrás do outro”. Então o caçador pergunta: Por acaso, a beleza é um pecado? A rainha diz: "Sim"! E ele responde: "Poxa, e eu que nem me confessei!" Ou ainda quando Branca de Neve conversa com uma cigarra na floresta e pergunta: “Como está seu marido?” E ela responde: "Ele foi fumado!" Há vários trocadilhos que deixam a história divertida. Por ser um seriado famoso e popular, conseguiu prender a atenção dos alunos e eles se divertiram muito, particularmente, gostaram da canção que os sete anões sempre cantavam, chamada "Tchuin tchuin tchunclain" e cantaram diante do vídeo. Lembramos que este mesmo episódio do Chaves pode ser encontrado também na forma de livro, gibi e videogame. Ao final debatemos sobre o que havia de diferente na história e o efeito de humor obtido, uma vez que eles deram boas gargalhadas.

\footnotetext{
${ }^{4}$ ALICE NO PAÍ́S DAS MARAVILHAS. Direção de Tim Burton. EUA: Walt Disney Pictures. DVD (1h $48 \mathrm{~min}$ ), legendado. (EUA, 2010)

${ }^{5}$ Site oficial: www.turmadochaves.com
} 
No segundo dia de oficina, partimos então para uma abordagem dos contos de fadas mais encontrados nos tempos modernos, visto que no primeiro dia concedemos bom espaço às versões antigas. Os alunos assistiram a um vídeo com os personagens de Maurício de Souza com a turma da Mônica, em que Magali fazia o papel de Chapeuzinho e de repente para e grita que já se cansou e questiona por que todas as vezes tem que ser sempre igual, já que ela já se cansou da mesma história. A partir daí pudemos abordar as mudanças nestas histórias. A frase da personagem foi muito persistente para auxiliar a introdução do assunto. No trecho Magali se cansa de ser Chapeuzinho e; parte para Hollywood, pois, quer ser atriz profissional e interpretar outros papéis, ter novas falas, porque já cansou de interpretar sempre a mesma história. E os outros personagens saem à procura de uma nova Chapeuzinho. Asserção semelhante faz Monteiro Lobato, ao ponderar que: "Tenho notado que muitos dos personagens das minhas histórias já andam aborrecidos de viverem toda a vida presos dentro delas. Querem novidade. Falam de correr o mundo a fim de se meterem em novas aventuras." (LOBATO, 1993, p.11)

Interpelamos os alunos perguntando se copiar a história de outra pessoa é certo ou se é um crime. Eles afirmaram convictos que copiar uma história é um crime. Perguntamos, então, se a história que eles assistiram consistia em um erro, uma vez que recontava uma história já conhecida. Eles ficaram confusos. Até que um dos alunos nos disse que não se pode copiar tudo igualzinho, mas se você mudar algumas coisas aí pode. Introduzimos, então, os conceitos de paródia e intertextualidade. Optamos por trabalhar com outras versões de Chapeuzinho. Projetamos o texto no telão e convidamos dois alunos para ir à frente ler o texto de Chapeuzinho Vermelho de Raiva, de Mário Prata para os colegas e, discutimos com os alunos esta versão. Neste texto, conhecemos uma Chapeuzinho mais moderna e até mesmo rebelde em um diálogo com a avó, no qual dispara as divergências de ideias típicas de uma conversa entre uma jovem na atualidade e uma senhora idosa. Depois, os alunos assistiram a um vídeo da história de Fita Verde no Cabelo, escrita por João Guimarães Rosa, e montada sob o modelo do jogo The $\operatorname{Sims}^{6}$, como se a história se passasse dentro do jogo. A familiaridade com o jogo despertou a atenção dos alunos que, no entanto, ficaram surpresos e assustados com o final da história, visto que, nela, não há o paradigma do final feliz e a avó morre

\footnotetext{
${ }^{6}$ Nome de uma série de jogo eletrônico de simulação de vida criada pelo designer de jogos Will Wright em 2000. The Sims usa uma combinação de técnicas gráficas em 3D e 2D.
} 
diante dos olhos da neta. Foi curioso perceber a expressão facial dos jovens e a tristeza com a morte da personagem. A falta do final feliz causou um estranhamento. Na sequência, os alunos foram convidados a ler a versão chamada Chapeuzinho Azul, em que o personagem principal é um menino que vai visitar seu avô. Curiosamente o texto fora escrito por um aluno de $6^{\circ}$ ano de uma escola estadual, o que nos serviu de propósito para dizer aos alunos que eles também são capazes e desafiá-los a escrever um texto criando uma nova versão de chapeuzinho. Apesar da preguiça de alguns e da conversa que eles insistiam em instaurar, eles conseguiram produzir os textos. Pedimos a três alunos

Dentre os vários alunos que se ofereceram para ir à frente da sala e ler suas histórias aos colegas, escolhemos três, aleatoriamente. Como encerramento da oficina, os alunos assistiram ao clipe da música "João e Maria" de Chico Buarque e ouviram a música tema do clássico de mesmo nome "A Bela e a Fera" ; como uma forma de mostrar uma aproximação com os contos de fadas não apenas da literatura, mas também através de outras artes, como a música. Nesse momento, muitos deles deixaram de lado as cadeiras e foram se sentar no chão, mais próximos do telão. Encerramos com um clima bem descontraído.

\section{OS ALUNOS AUTORES}

Os textos dos alunos esbanjaram criatividade. Deram continuidade à tradição ao começar os textos com o "Era uma vez...", já que, perceptivelmente, 99\% dos alunos utilizaram essa fórmula de entrada para adentrar os contos de fadas e, a partir daí, propuseram novos desenlaces, recorreram aos clássicos, preservaram algumas características ou propuseram outras totalmente novas. A frase final "e foram felizes para sempre..." não teve tamanha incidência quanto a outra.

O primeiro elemento a ser considerado na escrita dos alunos é justamente aquilo com que primeiro nos encontramos: o título. Nos títulos prevaleceu o uso de um objeto ou característica, nesse caso o Chapeuzinho, que veio acompanhado de alguma cor. A não atribuição de nome ao personagem, a sua não-identificação e referência a um objeto é relevante porque facilita a identificação do leitor com o personagem. Um dos nossos

\footnotetext{
${ }^{7}$ Versão em português da canção original "The Beauty and the Beast”.
} 
autores, porém rompe ao nomear uma vovó Dilma, em seu conto. A cor também é algo que não pode passar despercebido. Em Chapeuzinho Vermelho, cabe lembrar que o vermelho é a cor do proibido, da sensualidade e é uma cor que chama atenção. $\mathrm{O}$ vermelho de Chapeuzinho reforça a lembrança da iniciação sexual da menina. Já em Fita Verde no Cabelo, o verde ao contrário do vermelho, indica o "sinal aberto", a permissão para avançar. O verde também nos remete à maturidade, ao crescimento, o que é outra característica marcante nesta personagem. Se optarmos por uma leitura política, Fita Verde foi escrito na época da ditadura militar no Brasil, o que nos faz pensar em esperança e até mesmo no verde do nacionalismo, tão enfatizado na época. É a cor do Brasil. A cor nos textos dos alunos, ao contrário da simbologia que carregava nos clássicos, parece ser apenas uma questão de identificação pessoal, utilizaram a cor de que mais gostam para atribuir o título. Talvez isso justifique o porquê de a maioria das meninas nomearem uma Chapeuzinho Rosa.

Para início de conversa, em uma dessas histórias, há um Chapeuzinho Preto que, quando chega à casa da vovozinha, a casa é arrombada e eles enfrentam o lobo, que responde que quer apenas um pedaço de pizza. O próprio lobo é quem vai afirmar que violência não leva a nada, e eles acabam fazendo amizade com o lobo. Nossa autora aqui faz questão de enfatizar que tal episódio fez surgir uma amizade. A criança revela através de seus escritos um sentimento que encobria seu ser no momento da criação e que fica revelado em sua obra. É o que nos traz Bettelheim:

\footnotetext{
Percebi que esses contos, num sentido bem mais profundo do que outros tipos de leitura, começam onde a criança realmente se encontra no seu ser psicológico e emocional. Falam de suas pressões internas graves de um modo que ela inconscientemente compreende e - sem menosprezar as lutas interiores mais sérias que o crescimento pressupõe - oferecem exemplos tanto de soluções temporárias quanto permanentes para dificuldades prementes. (1980, p.14)
}

Parece mesmo que as crianças gostaram de caracterizar um lobo faminto, ou talvez isso queira dizer que já se aproximava a hora do almoço e elas tinham fome no momento em que escreveram seus contos. Há outra versão em que a garota, que agora é a Chapeuzinho Lilás, é abordada pelo lobo mau que a pára na estrada. A menina hesita, tem medo. Mas, ele apenas diz que tem fome. Então ela lhe dá dois bolinhos e ele educadamente agradece e vai embora satisfeito. O lobo aqui é educado, dá um bom exemplo para as crianças.

De modo geral, podemos dizer que a caracterização da personagem central oscilou entre personagem feminina ou masculina de modo igual, sem indícios de 
preferência por uma ou outra. Os alunos deixaram um pouco de lado a imagem de cidadezinha, vilarejo ou floresta e começaram a investir em um cenário mais urbano, rua escura, beco, cidade. Como destaca Silva (2008, p.70), são os novos caminhos que nos levam aos contos de fadas:

\begin{abstract}
Hoje, castelos e palácios cederam lugar a apartamentos, reis e rainhas persistem apenas nas cartas do baralho, os lobos estão em extinção, caçadas e caçadores deixaram de ser politicamente corretos, as moças não mais se enclausuram em casa, e pouquíssimas são as que ainda sabem fiar, tecer ou bordar. Contudo, as histórias de fadas ainda exercem seu poder de sedução junto a leitores de qualquer idade. Sob disfarces, elas podem ser reencontradas no cinema, na TV e na literatura.
\end{abstract}

Deparamos então com uma Chapeuzinho indo visitar a vovó em determinado bairro da própria cidade, logo após sair da escola enquanto os pais trabalham. A caracterização de um espaço familiar ao autor é nítida: "Seu pai certo dia fez hambúrguer e hot dog e pediu para que sua filha Chapeuzinho Rosa que pegasse uma cesta, colocasse alimentos, pegasse seu skate e levasse à sua avó que mora no bairro Tabajaras, esquina com o Renê, e Chapeuzinho Rosa levou."

Conhecemos nesses contos de fadas novos vilões. O lobo é facilmente substituído por um mendigo ou drogado, por exemplo. Prevalece a imagem do mau como feio em oposição ao bom que nos é dado como belo. A contextualização da história se aproximou mais da realidade deles. É o caso, por exemplo, do texto intitulado Chapeuzinho Preto, em que temos um personagem central masculino que vai levar algumas coisas que seu pai, que estava no serviço, havia esquecido de levar. Para chegar até o trabalho do pai, o menino atalha e passa pela floresta e é abordado por um mendigo drogado que começou a correr atrás dele. Porém, o menino é esperto e chega primeiro ao trabalho do pai, conta para ele o ocorrido, e o pai vai atrás do mendigo e lhe dá uma surra para ele aprender a não perseguir crianças mais. Temos aqui a questão da moral da história, pois o pai dá uma lição no mendigo para aprender a não mexer com crianças e é nítida também a figura do pai como o herói, aquele que salva o filho. Não há interferência de poderes sobrenaturais alterando o rumo das ações. A inovação consiste em não convocar um ser superdotado, como uma fada, gênio, feiticeiro ou objetos mágicos com poderes sobrenaturais para salvá-lo, essa função cabe ao próprio pai. Ao final, porém, o menino sentiu pena do mendigo. $O$ fato de ter pena do vilão é elemento novo, visto que nos clássicos a punição, o castigo da figura do mal, é desejada e comemorada. O mal é punido para que a justiça seja realizada e para que sua punição sirva como exemplo. Isso serve também para demarcar a nítida fronteira entre o bem e o 
mal. O personagem do bem se salva e tem motivos para comemorar. Como afirma Bettelheim (1980, p.109), “A criança sente que tudo vai bem com o mundo, e que pode ficar segura nele, apenas se os maus são castigados no final."

Somada a essa demarcação nítida de fronteiras entre o bem e o mal, há uma ampliação do castigo do mau e da recompensa do bem. Assim, o castigo, a morte e o sofrimento só poderiam acontecer com personagens do mal. Tentou-se severamente, ao longo dos anos, retirar qualquer resquício de sangue dessas histórias, privilegiando versões mais amenas. Sobre este assunto, pondera Marina Colasanti, em entrevista concedida em 2006:

Todos nós lembramos ainda o momento - em que os contos de fadas foram mandados para a tinturaria, a fim de limpá-los de qualquer mancha de sangue. O resultado foi que, ao limpar-se o sangue visível, drenou-se também o invisível, aquele que corre na veia das histórias, que lhes anima e lhes dá vida. E os belos contos de fadas ficaram pálidos, fracos, com um pé na UTI. (COLASANTI, apud SILVA, 2008, p. 70)

Dessa forma, a morte não tem espaço nesses contos. E sua ausência acaba por ajudar na formação do final feliz. No entanto, alguns alunos produziram textos com perspectiva semelhante à que eles leram em Fita Verde, com a morte da avó no final, exemplo do final não feliz. Uma das alunas diversifica já no título, Chapeuzinho Fita Azul no Cabelo, em que une o chapeuzinho e a fita. Talvez fosse mais um acessório, chapeuzinho com uma fita azul no cabelo. Nessa história, a menina ao chegar à casa da avó se depara com ela passando mal e, ao perguntar se está tudo bem, a avó responde que faltam poucos minutos para ela partir para onde o avô da menina está, no céu. As últimas palavras da senhora são um pedido para a menina cuidar bem de sua mãe. Ela dá um suspiro final diante da menina, que vai correndo, assustada, ao encontro da mãe, como se quisesse fugir daquela realidade. A menina começou a chorar e nunca mais voltou para a floresta.

Os alunos também variaram no conteúdo da cesta que a criança iria levar, os tradicionais bolinhos, bolo e doces foram substituídos por pizza, hambúrguer, cachorro quente e até chocolate, visivelmente lanches que agradam mais a criança contemporânea. Outras chapeuzinhos levaram cesta básica completa ou mesmo remédios. Em A Chapeuzinho Amarelo, o lobo aborda Chapeuzinho na estrada, e pergunta o que ela tem na cesta, quando ela diz que tem arroz, feijão e macarrão para levar para a avó, o lobo diz que aquelas coisas ele não queria. Ela se irrita e o ofende dizendo que não daria mesmo, ele sai xingando. 
Outro destaque foi Chapeuzinho Rosa, a menina que foi levar hambúrguer para a avó. Chapeuzinho Rosa tem esse nome porque sua avó lhe deu uma blusa com capuz rosa. A menina descreve que a avó mora perto da escola. Ela vai de skate levar a cesta para a avó, mas mesmo assim demora porque pára muitas vezes no sinaleiro. A menina morava com o pai, que era profissional culinário, e sua mãe havia morrido. No caminho alguns maníacos a convidam para fumar um "brown". A menina recusa e eles vão embora, mas quando ela chega à casa da vovozinha há muita confusão e vários policiais. Ela chega assustada e quer saber o que aconteceu. O fato é que a vovó, que já andava meio esquecida, foi à panificadora e pegou alimento sem pagar. Ela pediu que soltassem sua avó, pagou a fiança e eles foram embora. Então, ela discutiu com a avó, entregou a cesta e foi embora. O novo autor, aqui, soube criar um efeito de humor, com o pai que é profissional culinário, mas manda hambúrguer para a avó, a menina que anda de skate na floresta e tem que parar no sinaleiro, ou a avó que anda "caduca" e esquece-se de pagar a conta na padaria.

Alguns ainda recorreram aos contos de fadas em que, ao final, há a formação de um casal. A menina chega à casa da avó após uma aventura e afirma ter muito medo do lobo. A velha a adverte e diz que não precisa ter medo. A avó, por sua vez, está muito feliz, e Chapeuzinho admira tal fato, então pergunta por que a vovó estava tão feliz, ela responde que é porque vai se casar. A garota fica curiosa para saber com quem, e a senhora responde que se casaria com o lobo. A menina desmaia. Ao acordar, diz que matou o lobo porque tinha medo dele. A avó começou a chorar e a bater na menina. Contudo, acabou perdoando a menina e, como não queria ficar sozinha, resolve então se casar com o caçador e viveram felizes para sempre. O aluno ainda desenhou um coração ao final da folha com a frase: final feliz. O final feliz também pode ser observado em outras histórias, em que a menina gosta tanto de ir visitar a avó que resolve ficar morando com ela, ou passa a visitá-la todos os dias.

A maneira como o maravilhoso permeia a criação desses alunos também é marcante. Uma das alunas escreve uma história em que a vovó vê Chapeuzinho brigando com o lobo e acredita que tudo está de fato ocorrendo, mas Chapeuzinho conta para ela que se trata de um teatro e a vovó resolve participar também. Podemos ainda citar uma outra produção intitulada $\mathrm{O}$ Boné Preto. O menino da história era radical, e foi visitar sua avó de moto, fazendo motocross e rali pela floresta.

Creio ser revelado aqui o desejo dessa criança em participar dessa aventura de moto pela floresta, e esse desejo é realizado através de seu personagem. Como pontua 
Eduardo Brito (2008, p.381), “a literatura me é um meio de chegar lá onde meu limite físico não consegue me levar." Voltando ao Boné Preto, nessa história o chapéu está fora de moda, por isso prefere o boné. Quando o menino chegou ao seu destino, a avó estava brigando com o lobo, ele entrou na briga e logo chegou o caçador e começou a brigar também. Então chegou a PM (polícia militar) e, diante de tanta confusão, "botou todo mundo em cana", e o pequeno autor termina da seguinte forma: "e ninguém saiu até hoje...", ao contrário dos colegas que terminam suas histórias com um ponto final, esse dá uma idéia de continuidade, e deixa o final a cargo do leitor. Isso nos remete a Mário Quintana quando diz que as reticências são como os três primeiros passos de um pensamento que continua por conta própria o seu caminho. ${ }^{8}$

Os alunos também inovaram na caracterização das personagens, como um Chapeuzinho Preto que caiu em uma armadilha preparada pelo lobo, machucou o calcanhar e teve que terminar de chegar à casa da avó mancando, ou uma vovó que luta karatê e, é capaz de aplicar um golpe e jogar o lobo longe. Curiosamente, já existe também um caçador gay que se assusta com a situação e desmaia. $\mathrm{O}$ autor mirim nesse conto trabalha com o estereótipo que a sociedade assume de que o indivíduo gay é frágil e se assusta facilmente. Tal estereótipo é utilizado sob o pretexto de trazer humor à história.

Houve ainda uma produção em que Chapeuzinho encontra pelo caminho uma senhora. Em um primeiro momento esse enredamento nos remete à bruxa disfarçada de velhinha que Branca de Neve encontra pelo caminho e lhe oferece a maçã envenenada. Porém, nesta história, a velhinha aborda a menina pelo bosque e pede as coisas que ela levava na cesta para a sua avó. A senhora pedia porque tinha fome e estava doente. A menina viu que a senhora lembrava muito as condições de sua avó e teve pena. Então lhe deu os alimentos, e chamou a polícia, que a levou para um orfanato. Imaginamos que a criança quisesse se referir a um abrigo. Chegando à casa da vovó, a menina comeu a sopa que avó havia feito porque era tempo de frio, e todo o dia ia visitar a avó para ver se ela estava bem de saúde.

De modo geral, podemos dizer que nos surpreendemos com os textos dos alunos. Não que a expectativa fosse outra, mas eles sempre conseguem nos mostrar que são capazes de ir além do que imaginamos. Ficamos satisfeitas em ler as produções e perceber que eles chegaram a um ponto que era nosso objetivo. Foram capazes de, a

\footnotetext{
${ }^{8}$ Pensamento disponível em: www. usinasdeletras.com.br
} 
partir das leituras feitas em sala de aula e de outras leituras ao longo de suas vidas, mudar a escrita dos contos de fadas e lhes dar nova roupagem. Escreveram contos de fadas, num estilo moderno, deixando livre sua imaginação e esperamos que possam ter chegado a uma nova dimensão do ler e fazer texto literário.

\section{CONSIDERAÇÕES FINAIS}

Este ensaio se propôs a resumir as oficinas realizadas através de um projeto de extensão, a realização da disciplina Prática de Ensino de Literatura. Vale ressaltar, que antes de darmos início às oficinas, foram realizados encontros para preparação teórica dos professores em formação e também para planejamento do projeto. Podemos considerar que as discussões teóricas foram muito produtivas, pois, estas discussões forneceram uma base sólida e coerente em nossa formação enquanto futuros professores. Os textos trabalhados proporcionam uma boa reflexão e são textos aos quais recorreremos sempre que necessário, pois, como afirma Paulo Freire, todo professor é necessariamente um pesquisador, visto que não existe ensino sem pesquisa. Ser pesquisador não é uma função extra ao trabalho do professor, mas é condição do ser professor. Ressaltamos que, antes da execução das oficinas, os professores em formação participaram de aulas teóricas que versavam sobre o ensino de literatura, posteriormente, precedeu-se ao planejamento da oficina, como forma de pesquisa-ação, um espaço para concretizar as ideias e reflexões levantadas em sala de aula. Além disso, a própria oficina serviu como fomento à pesquisa. Acreditamos, então, que todo professor é condicionalmente pesquisador, embora o inverso não seja verdadeiro. Como aponta Freire (1996, p.29):

\footnotetext{
Fala-se hoje, com insistência, no professor pesquisador. No meu entender o que há de pesquisador no professor não é uma qualidade ou uma forma de ser ou de atuar que se acrescente à de ensinar. Faz parte da natureza da prática docente a indagação, a busca, a pesquisa. $\mathrm{O}$ de que se precisa é que, em sua formação permanente, o professor se perceba e se assuma, porque professor, como pesquisador.
}

Assim, enquanto professoras em formação, temos a crença de que se faz importante ficarmos atentas aos questionamentos que surgirão ao longo de nossa prática e desenvolver essas perguntas que surgem, pois concordamos que "como professor devo saber que sem a curiosidade que me move, que me insere na busca, não aprendo nem ensino" (FREIRE, 1995, p.85, grifo do autor). 
E, de fato, depois de adentrar a sala de aula, constatamos que sempre há muito a se aprender e descobrir, e que os alunos, enquanto seres humanos, não são seres programáveis, que se possa controlar o que aprendem, o que dizem e seu comportamento. A sala de aula é acima de tudo um lugar de encontros, de alunos diferentes, de professores multifacetados e também humanos diante de suas limitações, encontro de culturas e de assuntos diversos. Uma aula pode ser repetida inúmeras vezes na mesma sala e ainda assim nunca será a mesma. Isso é próprio da literatura, uma leitura nunca é igual a outra, é sempre algo novo. A sala de aula desperta também essa vontade e o interesse em ser professor pesquisador por se aliar a uma sede de conhecimento e a uma prática reflexiva que busca ser cada vez mais aprimorada.

Partindo da premissa de que a literatura é um direito de todo ser humano, é um bem imensurável (BRITO, 2008), trabalhar com literatura exige um compromisso e um envolvimento muito sério; em outras palavras, trabalha-se com um direito universal do ser humano, e esse direito deve ser respeitado. Mas sob a ótica de que é um direito, e ao mesmo tempo um dever, aí temos ainda mais ressaltada a árdua missão de professores, como lidar com algo que é um direito e que se caracteriza como um dever, e um dever que se caracteriza com direito? Do ponto de vista Antonio Candido (1995), a literatura é um bem incompressível, ou seja, a fruição da literatura é fundamental ao ser humano.

Ao realizarmos o projeto de extensão descrito neste ensaio, tivemos a chance de constatar que os filmes, seriados e desenhos são uma excelente ferramenta de trabalho para despertar nos jovens alunos de ensino básico o interesse para lerem os textos literários, além de mostrar para os professores-alunos outras possibilidades de se trabalhar a leitura, fugindo, um pouco, da tradicional e, muitas vezes, exclusiva leitura do livro didático. Com a análise dos dados obtidos e as reflexões que fizemos sobre as produções feitas pelos alunos, fomos remetidas a perceber que lidar com contos de fadas é mexer com a criatividade dos alunos e com sua curiosidade diante da leitura.

Afirmamos que a preparação e organização das oficinas foi uma experiência positiva. Voltar às escolas e ver como anda o ensino na cidade, ter contato com outros professores, ensinar a alunos tão diversos, tudo isso é significativo. Nos sentimos encorajadas a afirmar que foi, de fato, proveitoso. O primeiro contato com a função de ensinar sendo bem acompanhado por alguém experiente pode servir como elemento motivador também, pois transmite segurança aos futuros professores.

Podemos ainda dizer que foi uma sensação boa perceber que boa parte dos objetivos propostos para este projeto foram alcançados, pela participação dos alunos e 
pela facilidade com que eles desenvolveram suas produções. Ficamos contentes e surpreendidas com os bons textos que produziram. É uma sensação positiva se surpreender com os alunos, o que ocorre que quando eles mostram que são escritores em potencial. Isso nos faz pensar em Gabriel Chalita (2008, p.138) quando diz que o professor jamais pode desistir de suas sementes, pois: "Ser professor é semear em terreno sempre fértil e se encantar com a colheita". Nós conseguimos nos encantar com a colheita. Ousamos afirmar que eles aprenderam o conteúdo que planejamos e, quando o professor percebe que seu aluno aprendeu, essa é a maior recompensa que ele pode ter enquanto educador. O nosso final feliz não veio de poderes mágicos como nos contos de fadas, veio do retorno por parte dos alunos. Acima de tudo, fica a certeza de nossa principal missão: formar leitores. O gosto pela leitura é algo que não pode ser ensinado, mas pode e deve ser encorajado.

Por fim, ao traçarmos através deste artigo a constituição e realização deste projeto de extensão, esperamos contribuir com pesquisas e projetos futuros que conciliem extensão e ensino de literatura. Esperamos ainda, que a experiência acima descrita possa encorajar graduandos do curso de Letras a fomentarem novos projetos nesse sentido, uma vez que podem trazer contribuições significativas ao ensino de literatura.

\section{REFERÊNCIAS BIBLIOGRÁFICAS}

BAKHTIN, Mikhail. A cultura popular na idade média e no renascimento: o contexto de François Rabelais. São Paulo: Hucitec, Brasília: Editora da Universidade de Brasília, 1987.

BETTELHEIM, Bruno. A psicanálise dos contos de fadas. Trad. Arlene Caetano. $16^{\mathrm{a}}$ ed. São Paulo: Terra e Paz, 2002. (versão digitalizada)

BETTELHEIM, Bruno. A psicanálise dos contos de fadas. Rio de Janeiro: Paz e Terra, 1980.

BRITO Eduardo Manoel de. Reflexões sobre a literatura e os direitos humanos. In: BITTAR, Eduardo C. B. (Org.). Educação e metodologia para os direitos humanos. São Paulo: Quatier Lantin, 2008.

CANDIDO, Antônio. A literatura e a formação do homem. In: Ciência e Cultura. São Paulo, v.24, n 9. p. 803-809, set.1972. 
CHALITA, Gabriel. Pedagogia da Amizade. São Paulo: Gente, 2008.

FREIRE, Paulo. Pedagogia da autonomia: saberes necessários à prática docente. 33 ed. Rio de Janeiro: Paz e Terra, 1996.

LARROSA, Jorge. Pedagogia profana: danças, piruetas e mascaradas. Trad. Slfred Veiga Neto. Belo Horizonte: Autêntica, 2000.

LOBATO, José Bento Monteiro. Reinações de Narizinho. São Paulo: Brasiliense, 1993.

PRATA, Mário. Chapeuzinho Vermelho de Raiva. Disponível em: http://www.marioprataonline.com.br/obra/literatura/infanto/chapeuzinho/chapaeuzinho. htm. Acesso em: 22/04/2011

PERROTTI, Edmir. A expansão do discurso utilitário: a literatura para crianças e jovens no Brasil/ As novas concepções de literatura para criança no Brasil: a crise do utilitarismo. O texto sedutor na literatura infantil. São Paulo: Ícone, 1986.

SILVA, Vera Maria Tiezmann. Literatura infantil brasileira: um guia para professores e promotoers de leitura. Goiânia: Cânone Editorial, 2008.

ZILBERMAN, Regina. A leitura e o Ensino da Literatura. São Paulo-SP; Contexto, 1988.

WERNER, M. Da fera à loira: sobre contos de fadas e seus narradores. Tradução Thelma Médici Nóbrega. São Paulo: Companhia das Letras. 1999. 